\title{
PENGARUH GAYA KEPEMIMPINAN TERHADAP DISIPLIN KERJA DAN DAMPAKNYA TERHADAP KINERJA KARYAWAN
}

\author{
Maudy Rosalina ${ }^{1}$, Lela Nurlaela Wati ${ }^{2}$ \\ ${ }^{1}$ STIE Muhammadiyah Jakarta, maudyrosalina@gmail.com \\ ${ }^{2}$ STIE Muhammadiyah Jakarta, lela_nwm@yahoo.com
}

\begin{abstract}
ABSTRAK
Penelitian ini bertujuan untuk menganalisis bukti empiris pengaruh gaya kepemimpinan terhadap kinerja karyawan melalui disiplin kerja. Penelitian ini menggunakan pendekatan sensus, dimana semua anggota populasi dijadikan sebagai responden dengan jumlah 52 karyawan PT. XYZ Divisi EPC. Analisis data yang digunakan adalah Structural Equation Modeling (SEM). Hasil penelitian menunjukkan bahwa terdapat pengaruh positif dan signifikan antara gaya kepemimpinan terhadap disiplin kerja, disiplin kerja terhadap kinerja karyawan. Secara langsung, gaya kepemimpinan tidak berpengaruh terhadap kinerja karyawan, namun secara tidak langsung berpengaruh terhadap kinerja karyawan. Hasil ini menunjukkan bahwa semakin baik gaya kepemimpinan maka disiplin kerja dan kinerja karyawan akan semakin meningkat. Peningkatan disiplin kerja dalam kepemimpinan perusahaan mampu meningkatkan kinerja yang optimal.
\end{abstract}

Kata kunci: Gaya Kepemimpinan, Disiplin Kerja, Kinerja Karyawan,

\begin{abstract}
This study aims to analyze empirical evidence of the influence of leadership style on employee performance through work discipline. This study uses a census approach, where all members of the population are made as respondents with a total of 52 employees of PT XYZ, EPC Division. Analysis of the data used is Structural Equation Modeling (SEM). The results showed that there was a positive and significant influence between leadership style on work discipline, work discipline on employee performance. Directly, leadership style does not affect employee performance, but indirectly affects employee performance. These results indicate that the better the leadership style, the work discipline and employee performance will increase. Increased work discipline in corporate leadership can improve optimal performance.
\end{abstract}

Keywords: Leadership Style, Employee Performance, and Work Discipline.

Naskah diterima : 14-02-2020, Naskah dipublikasikan : 31-03-2020

\section{PENDAHULUAN}

Keberhasilan suatu organisasi dipengaruhi oleh kinerja individu karyawannya. Suatu organisasi akan berupaya untuk meningkatkan kinerja karyawannya dengan harapan tujuan perusahaan dapat tercapai. Kinerja pada dasarnya adalah apa yang dilakukan atau tidak dilakukan karyawan. Kinerja karyawan adalah yang mempengaruhi seberapa banyak mereka memberi kontribusi kepada organisasi antara lain termasuk kuantitas output, kualitas output, jangka waktu output, kehadiran ditempat kerja dan sikap kooperatif (Mathis dan Jackson, 2002). Salah satu 
factor yang dapat menentukan baik buruknya kinerja karyawan adalah gaya kepemimpinan di perusahaan. Gaya kepemimpinan merupakan norma perilaku yang digunakan oleh seseorang pada saat orang tersebut mencoba mempengaruhi perilaku orang lain seperti yang diinginkan. Dalam organisasi, suatu gaya kepemimpinan yang tepat sangat diperlukan untuk mengembangkan lingkungan kerja yang kondusif dan meningkatkan kinerja bagi karyawan sehingga diharapkan akan menghasilkan produktivitas yang tinggi (Ardana, d.k.k, 2012). Sebaliknya gaya kepemimpinan yang tidak disesuaikan dengan karakteristik karyawan dan tugas yang ada, dapat mendorong pegawai merasa kurang bersemangat dalam bekerja bahkan kehilangan semangat kerja, sehingga menyebabkan karyawan tidak bersungguh-sungguh dalam bekerja dan perhatian yang tidak terpusat pada pekerjaan. Tentu saja hal ini perlu mendapatkan perhatian khusus karena dapat mengganggu kelancaran suatu kegiatan.

Selain gaya kepemimpinan, disiplin kerja juga memiliki aspek yang mempengaruhi penurunan pada kinerja karyawan. Kedisiplinan merupakan suatu hal yang menjadi tolok ukur untuk mengetahui apakah peran pemimpin secara keseluruhan dapat dilaksanakan dengan baik atau tidak. Disiplin kerja adalah tindakan manajemen untuk menegakkan standar organisasi (Davis dan Newstrom, 1985:87). Disiplin juga merupakan bentuk pengendalian dari karyawan dana pelaksanaan yang teratur menunjukkan tingkat kesanggupan tim kerja dalam sebuah organisasi, tindakan displin menuntut adanya hukuman terhadap karyawan yang gagal memenuhi standar yang ditentukan. Oleh karena itu tindakan disiplin tidak diterapkan secara sembarangan, melainkan memerlukan pertimbangan bijak. Ketika karyawan memenuhi peraturan yang telah ditetapkan oleh perusahaan dan mempunyai disiplin yang tinggi maka akan menciptakan suasana perusahaan lebih kondusif sehingga akan berdampak positif pada aktivitas perusahaan. Oleh karena itu, setiap perusahaan mempunyai harapan agar karyawan perusahaan dapat mematuhi peraturan yang telah ditetapkan.

Hasil penelitian terdahulu mengenai pengaruh gaya kepemimpinan terhadap disiplin kerja didokumentasikan oleh Tintami dkk (2013), Liyas (2017), Muthi dan Djuwita (2019) menunjukkan bahwa gaya kepemimpinan berpengaruh positif signifikan terhadap disiplin kerja. Hasil penelitian terdahulu mengenai pengaruh gaya kepemimpinan terhadap kinerja karyawan memberikan bukti yang beragam, dimana sebagian peneliti menghasilkan bahwa gaya kepemimpinan berpengaruh terhadap kinerja karyawan. Pengaruh positif gaya kepemimpinan terhadap kinerja karyawan dipublikasikan oleh Susanty dan Baskoro (2012), Wiratama dan Sintaasih (2013), Putra (2014), Iqbal et al. (2015), Chandra (2016), Fathia et al. (2018), Jayanti \& Wati (2019). Namun hasil penelitian yang berbeda didokumentasikan oleh Ariyani dan Ariyanto (2011), dimana gaya kepemimpinan tidak berpengaruh terhadap kinerja karyawan.

Begitu juga dengan hasil penelitian terdahulu disiplin kerja terhadap kinerja karyawan. Pengaruh positif disiplin terhadap kinerja karyawan didokumentasikan oleh Susanty dan Baskoro (2012), Wiratama dan Sintaasih (2013), Putra (2014), Suyono (2014), Hersona \& Sidharta (2016), Fathia et al. (2018). Namun hasil penelitian lain yang berbeda mengenai pengaruh disiplin kerja yang tidak signifikan didokumentasikan oleh Kurniawan dan Santoso. 2012.

Berdasarkan survei pendahuluan, peneliti mendapatkan informasi mengenai gaya kepemimpinan dan disiplin kerja serta kinerja karyawan melalui Kepala Bagian Sumber Daya Manusia (SDM) yang menyebutkan bahwa karyawan PT XYZ Divisi EPC masih terdapat karyawan yang menggunakan jam kerjanya tidak maksimal, adanya karyawan yang terlihat santai-santai dan berkeliaran seenaknya pada jam kerja, adanya karyawan yang menggunakan jam kerja untuk membuka media sosial dan menonton youtube. Banyaknya karyawan yang tidak disiplin yaitu datang tidak tepat waktu dan karyawan yang tidak menggunakan seragam kerja sesuai memo dinas yang ada. Kondisi ini terjadi bisa karena kurang tegasnya kepemimpinan di perusahaan tersebut dimana pimpinan kurang memberikan teguran kepada karyawan yang tidak mengikuti peraturan yang telah ditetapkan. Kurangnya komunikasi antara pimpinan dan bawahan. 
Pimpinan yang kurang berperan terhadap masalah yang ada. Pimpinan yang belum bisa mengatasi masalah dengan benar sehingga karyawan selalu menjadi target kemarahan.

Untuk menciptakan kinerja karyawan yang efektif dan efisien tidak mudah, tidak hanya menciptakan gaya kepemimpinan yang baik saja tetapi faktor disiplin kerja juga mempengaruhi. Oleh karena itu, pimpinan perusahaan dapat mendorong karyawan agar memiliki disiplin yang tinggi untuk mencapai tujuan perusahaan. Hal-hal di atas adalah masalah yang sangat penting untuk diperhatikan, dan jika dibiarkan maka akan mempengaruhi citra perusahaan dan akan berdampak pada penurunan kinerja karyawannya sehingga akan menghambat pencapaian visi dan misi perusahaan. Masalah-masalah tersebut dapat dihindari jika organisasi atau perusahaan mampu memberikan dorongan yang kuat kepada karyawannya untuk berdisiplin dan butuh suatu kerja keras secara bersama-sama dalam mewujudkan tujuan bersama perusahaan tersebut.

Berdasarkan uraian latar belakang tujuan penelitian ini adalah untuk menguji pengaruh gaya kepemimpinan terhadap disiplin kerja dan dampaknya terhadap kinerja karyawan. Penelitian ini berbeda dengan penelitian sebelumnya karena menguji gaya kepemimpinan terhadap kinerja baik secara langsung maupun tidak langsung melalui disiplin kerja di PT XYZ Divisi EPC.

\section{KAJIAN LITERATUR}

\section{Gaya Kepemimpinan}

Gaya kepemimpinan seorang pemimpin merupakan hal yang ikut menentukan keberhasilan pencapaian tujuan organisasi. Dan penerapan gaya memimpin antara satu organisasi dengan organisasi yang lain berbeda-beda sesuai dengan kondisi organisasi dan pola kerja anggota organisasi, sehingga dalam penerapannya gaya kepemimpinan ini akan meningkatkan kinerja para anggota organisasi.

Setiap pemimpin memiliki gaya kepemimpinan yang berbeda-beda. Dasar yang digunakan dalam memilih gaya kepemimpinan merupakan tugas yang harus dilakukan oleh pimpinan. Seorang pimpinan harus mempunyai kapasitas untuk membaca situasi yang dihadapi dan menyesuaikan gaya kepemimpinannya sesuai dengan situasi dan kondisi suatu organisasi. Adapun tiga ciri kepemimpinan transformasional yaitu karismatik, stimulasi intelektual dan perhatian secara individual Yukl (2002), Dengan demikian ciri-ciri kepemimpinan transformasional terdiri dari karismatik, stimulasi intelektual dan perhatian secara individual. kondisi tertentu.

\section{Disiplin Kerja}

Kedisiplinan merupakan salah satu fungsi manajemen sumber daya manusia yang terpenting karena semakin baik disiplin karyawan, semakin tinggi prestasi kerja yang dapat dicapainya. didiplin kerja merupakan sikap atau perilaku seseorang karyawan dalam bekerja untuk bersedia menaati atau mengikuti semua peraturan-peraturan perusahaan yang berlaku dengan maksud agar tujuan perusahaan tercapai secara optimal. Menurut Handoko dalam buku "Manajemen Personalia Dan Sumber Daya Manusia" (2008:208), ada dua tipe kegiatan pendisiplinan yaitu preventif dan korektif :

a. Disiplin preventif

Disiplin preventif adalah kegiatan yang dilaksanakan untuk mendorong para karyawan agar mengikuti berbagai standar dan aturan, sehingga penyelewengan-penyelewengan dapat dicegah.

b. Disiplin korektif

Disiplin korektif adalah kegiatan yang diambil untuk menangani pelanggaran terhadap aturan-aturan dan mencoba untuk menghidari pelanggaran-pelanggaran lebih lanjut. Kegiatan korektif sering berupa suatu bentuk hukuman dan disebut tindakan pendisiplinan (disciplinary action), berupa peringatan atau skorsing. Sasaran-sasaran tindakan pendisiplinan hendaknya 
positif, bersifat mendidik dan mengoreksi. Maksud pendisiplinan adalah untuk memperbaiki kegiatan diwaktu yang akan datang dan bukan menghukum kegiatan sebelumnya.

\section{Kinerja Karyawan}

Kinerja merupakan aspek penting dalam upaya pencapaian tujuan perusahaan. Dengan kinerja karyawan yang baik pada suatu peusahaan, maka perusahaan tersebut akan dapat mencapai tujuan yang diinginkannya.

Faktor-faktor yang mempengaruhi kinerja menurut Mangkunegara "Manajemen Sumber Daya Manusia Perusahaan" (2010:67) adalah faktor kemampuan dan faktor motivasi.

\section{a. Faktor Kemampuan}

Kemampuan seseorang karyawan terdiri dari kemampuan potensi (IQ) dan kemampuan reality (knowledge + Skill). Artinya jika karyawan memiliki $I Q$ di atas rata-rata (IQ 110-120) dengan pendidikan yang memadai untuk jabatannya dan terampil dalam mengerjakan pekerjaan sehari-hari, maka ia akan lebih mudah mencapai kinerja yang diharapkan.

b. Faktor Motivasi

Motivasi terbentuk dari sikap seorang karyawan dalam menghadapi situasi kerja. Motivasi karyawan merupakan kondisi yang menggerakkan diri karyawan yang terarah untuk mencapai tujuan kerja, sedangkan sikap adalah kondisi mental yang mendorong diri karyawan untuk berusaha mencapai prestasi kerja secara maksimal.

\section{Pengembangan Hipotesis}

Menurut Mathis dan Jackson (2002:314) disiplin merupakan bentuk pelatihan yang menegakkan peraturan-peraturan perusahaan. Menurut Hasibuan (2007:193) bahwa: "Kedisiplinan adalah kesadaran dan kesediaan seseorang menaati semua peraturan perusahaan dan norma-norma sosial yang berlaku. Menurut Rivai dan Jauvani (2009:825) bahwa: "Disiplin adalah suatu alat yang digunakan para manajer untuk berkomunikasi dengan karyawan agar mereka bersedia untuk mengubah suatu perilaku serta sebagai suatu upaya untuk meningkatkan kesadaran dan kesediaan seseorang untuk memenuhi peraturan-peraturan perusahaan".

Rivai dan Jauvani (2009), Liyas (2017), dan Muthi dan Djuwita (2019) dalam penelitiannya menunjukkan bahwa gaya kepemimpinan berpengaruh positif terhadap variabel disiplin kerja. Berdasarkan pernyataan di atas maka hipotesis pertama penelitian ini adalah :

\section{H1 : Gaya kepemimpinan berpengaruh positif terhadap disiplin kerja.}

Menurut Handoko (2008:208), ada dua tipe kegiatan pendisiplinan yaitu preventif dan korektif : Disiplin preventif adalah kegiatan yang dilaksanakan untuk mendorong para karyawan agar mengikuti berbagai standar dan aturan, sehingga penyelewengan-penyelewengan dapat dicegah. Disiplin korektif adalah kegiatan yang diambil untuk menangani pelanggaran terhadap aturan-aturan dan mencoba untuk menghidari pelanggaran-pelanggaran lebih lanjut. Kegiatan korektif sering berupa suatu bentuk hukuman dan disebut tindakan pendisiplinan (disciplinary action), berupa peringatan atau skorsing. Sasaran-sasaran tindakan pendisiplinan hendaknya positif, bersifat mendidik dan mengoreksi. Maksud pendisiplinan adalah untuk memperbaiki kegiatan di waktu yang akan datang dan bukan menghukum kegiatan yang lalu.

Susanty dan Baskoro (2012), Wiratama dan Sintaasih (2013), Putra (2014), Iqbal et al. (2015), Chandra (2016), Fathia et al. (2018), Jayanti dan Wati (2019) dalam penelitiannya menunjukkan bahwa gaya kepemimpinan berpengaruh positif terhadap variabel kinerja karyawan. Berdasarkan pernyataan di atas maka hipotesis kedua penelitian ini adalah :

\section{H2 : Gaya kepemimpinan berpengaruh positif terhadap kinerja karyawan.}

Pada dasarnya faktor yang mempengaruhi disiplin kerja berasal dari dua faktor, yaitu faktor intrinsik dan ekstrinsik. Helmi (1996:37) merumuskan faktor-faktor yang mempengaruhi disiplin kerja menjadi dua 
faktor, yaitu faktor kepribadian dan faktor lingkungan. Faktor yang penting dalam kepribadian seseorang adalah nilai yang dianut. Sistem nilai yang dianut ini berkaitan langsung dengan disiplin. Menurut Kelman (1985) perubahan sikap mental dengan perilaku terdapat tiga tingkatan yaitu disiplin karena kepatuhan, disiplin karena identifikasi, dan disiplin karena internalisasi.

Disiplin seseorang merupakan hasil dari sosialisasi dan interaksi dengan lingkungan, terutama lingkungan sosial. Disiplin kerja yang tinggi tidak muncul begitu saja tapi merupakan suatu proses belajar secara terus-menerus. Pemimpin merupakan agen pengubah dalam prosesnya perlu memperhatikan prinsip-prinsip konsisten, adil, dan bersikap positif dan terbuka. Susanty dan Baskoro (2012), Wiratama dan Sintaasih (2013), Putra (2014), Suyono (2014), Hersona \& Sidharta (2016), Fathia et al. (2018), dalam penelitiannya menunjukkan bahwa disiplin kerja berpengaruh positif terhadap variabel kinerja karyawan. Berdasarkan pernyataan diatas maka hipotesis ketiga penelitian ini adalah :

\section{H3: Disiplin Kerja berpengaruh positif terhadap Kinerja Karyawan.}

Mangkunegara (2010:131) mengemukakan bahwa ada empat pelaksanaan sanksi terhadap pelanggaran disiplin, antara lain : Pemberian Peringatan, Pemberian Sanksi Harus Segera, Pemberian Sanksi Harus Konsisten, Pemberian Sanksi Harus Impersonal. Menurut Hasibuan "Manajemen Sumber Daya Manusia (Edisi Revisi)" (2007:194), indikator-indikator yang mempengaruhi tingkat kedisiplinan karyawan suatu perusahaan adalah : Tujuan dan kemampuan, keteladanan pemimpin, Balas jasa, Keadilan, Waskat, Sanksi hukuman, Ketegasan, Hubungan kemanusiaan.

Gaya kepemimpinan yang dimiliki oleh pimpinan akan menentukan disiplin kerja karyawan sehingga tercapai kinerja yang maksimal. Susanty dan Baskoro (2012) dalam penelitiannya menunjukkan bahwa terdapat pengaruh positif antara gaya kepemimpinan terhadap disiplin kerja dan kinerja karyawan. Berdasarkan pernyataan di atas maka hipotesis keempat penelitian ini adalah :

\section{H4: Terdapat pengaruh positif antara pengaruh gaya kepemimpinan terhadap kinerja karyawan melalui disiplin kerja.}

Berdasarkan teori dan penelitian terdahulu yang dijelaskan di atas, maka penulis membuat kerangka pikir mengenai pengaruh gaya kepemimpinan terhadap disiplin kerja dan dampaknya terhadap kinerja karyawan sebagai berikut:

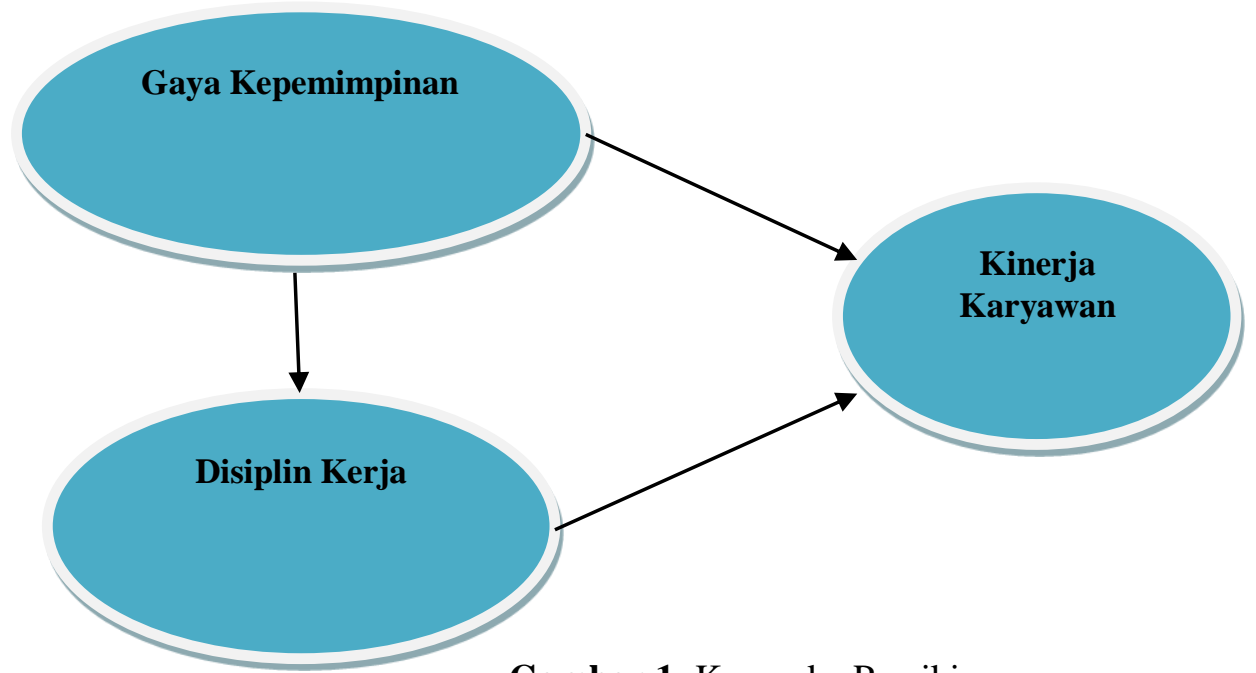

METODE PENELITIAN

Gambar 1. Kerangka Pemikiran 
Sampel dalam penelitian ini adalah seluruh karyawan PT XYZ Divisi EPC yang berjumlah 52 karyawan.

Berikut ini adalah variable, dimensi dan indicator yang digunakan dalam penelitian ini:

Tabel 1. Operasional Variabel

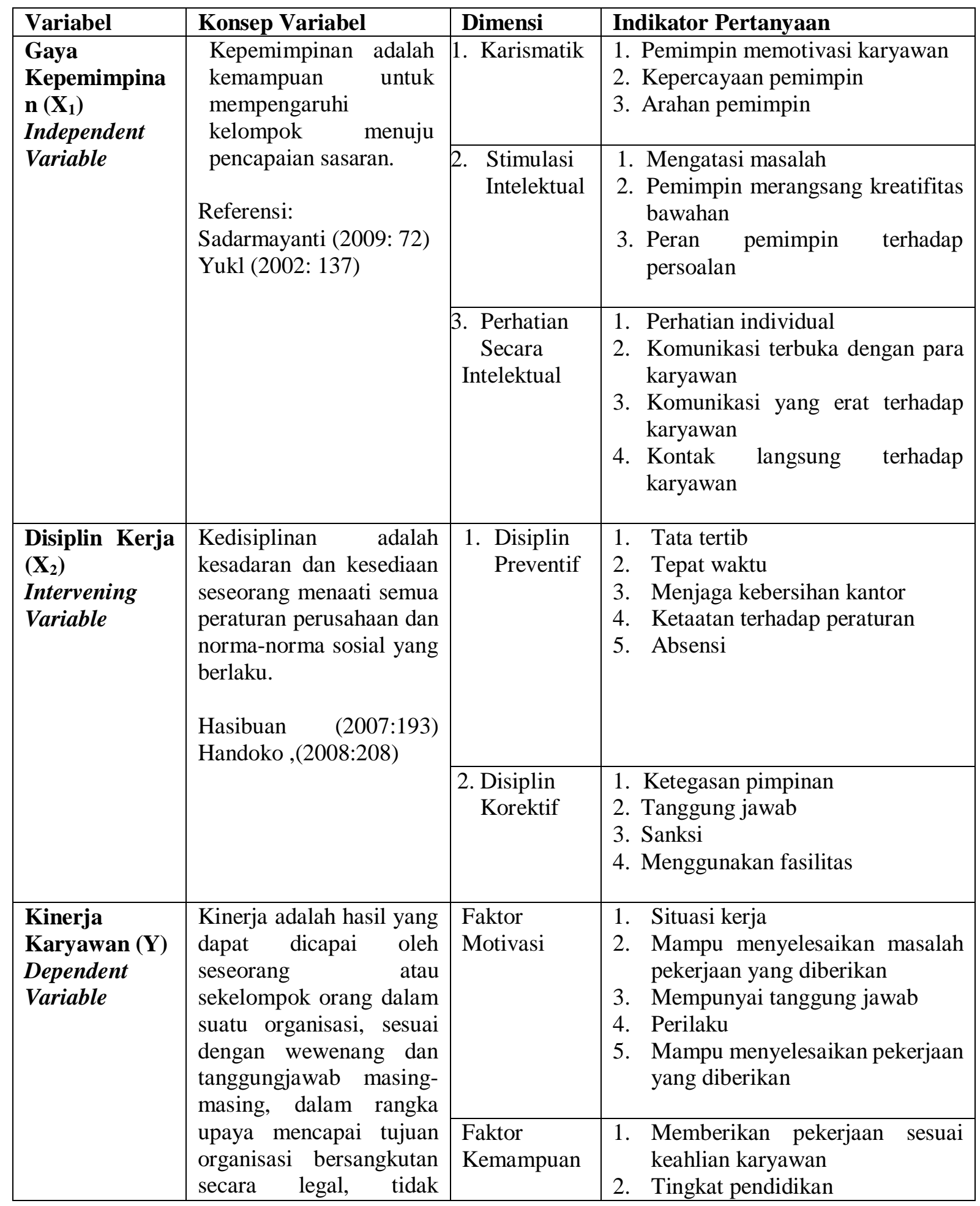




\begin{tabular}{|l|l|l|l|}
\hline & $\begin{array}{l}\text { melanggar hukum dan } \\
\text { sesuai dengan moral } \\
\text { maupun etika. } \\
\text { Prawirosentono (2010) } \\
\text { Mangkunegara (2010:67) }\end{array}$ & 3. $\begin{array}{l}\text { Mengerjakan pekerjaan dengan } \\
\text { penuh manfaat }\end{array}$ \\
4. Terampil dalam bekerja \\
\hline
\end{tabular}

Sumber : Data diolah

Penelitian ini menggunakan pendekatan Second order Confirmatory. Second order konstruk laten gaya kepemimpinan diukur dengan 3 First Order komponen yaitu karismatik, stimulasi intelektual, dan perhatian secara intelektual. Komponen karismatik diukur oleh indikator X1.1.1-X1.1.3, stimulasi intelektual diukur oleh indikator X1.2.1-X1.2.3, perhatian secara intelektual diukur oleh indikator X1.3.1 -X1.3.4. Konstruk laten disiplin kerja diukur dengan 2 First Order komponen yaitu disiplin preventif dan disiplin korektif. Komponen disiplin preventif diukur oleh indikator X2.1.1 -X2.1.5 dan disiplin korektif diukur oleh indikator X2.2.1 - X2.2.4. Konstruk laten kinerja karyawan diukur oleh 2 First Order komponen yaitu faktor kemampuan dan faktor motivasi. Komponen faktor kemampuan diukur oleh indikator Y1.1.1 - Y1.1.5 dan faktor motivasi diukur oleh indikator Y1.2.1 - Y1.2.4.

Dalam pendekatan repeated indicators, ukuran indikator X1.1.1-Y2.4 digunakan dua kali, dimana pertama diukur oleh First Order Confirmatory dan kedua untuk mengukur Second Order Confirmatory (Wati, 2018).

Berikut ini adalah gambar Full Structural Equetion Modelling penelitian ini:

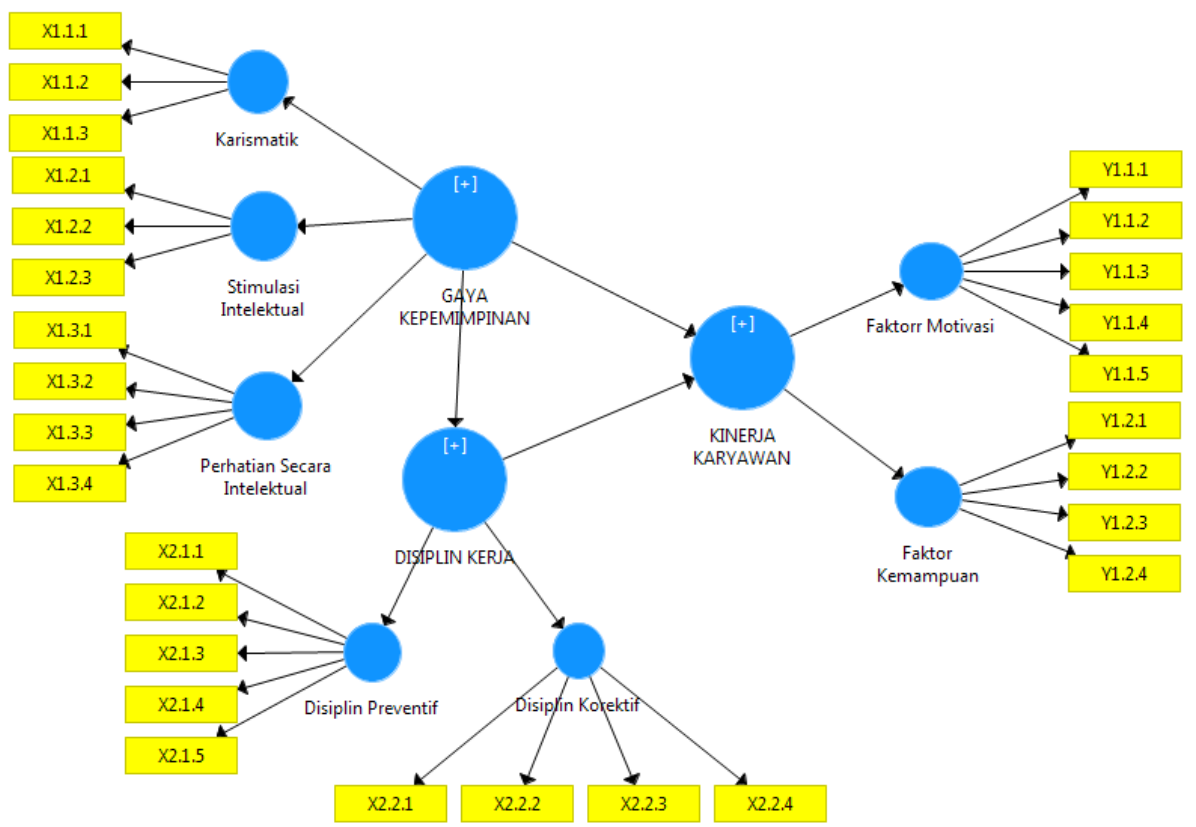

\section{Gambar 2. Model SEM}

Berdasarkan gambar model penelitian di atas, kemudian diterjemahkan ke dalam bentuk persamaan sebagai berikut :

$$
\begin{aligned}
& \mathrm{DK}=\beta_{1} \mathrm{GK}+\mathrm{e}_{1} \ldots \ldots \ldots \ldots . .(\text { Persamaan } 1) \\
& \mathrm{KK}=\beta_{2} \mathrm{GK}+\beta_{3} \mathrm{DK}+\beta_{4} \mathrm{DKGK}+\mathrm{e}_{2} \ldots \ldots \ldots \ldots . .(\text { Persamaan } 2)
\end{aligned}
$$


Keterangan :

$\beta=$ Koefisien Regresi

DK = Disiplin Kerja

GK = Gaya Kepemimpinan

KK = Kinerja Karyawan

$\mathrm{e}_{1}=$ Eror

$\mathrm{e}_{2}=$ Eror

\section{PEMBAHASAN}

Analisis Deskrips

Pada tahapan ini akan dilakukan analisis terhadap variabel-variabel penelitian berdasarkan item pertanyaan dalam kuesioner.

Tabel 2. Pedoman Kategorisasi Rata-Rata Skor Tanggapan Responden

\begin{tabular}{|c|c|}
\hline Interval & Kategori \\
\hline $1,00-1,79$ & Sangat Buruk/Sangat Rendah \\
\hline $1,80-2,59$ & Tidak Baik/Rendah \\
\hline $2,60-3,39$ & Cukup \\
\hline $3,40-4,19$ & Baik/Tinggi \\
\hline $4,20-5,0$ & Sangat Baik/Sangat Tinggi \\
\hline
\end{tabular}

Tabel 3. Deskripsi Variabel Penelitian

\begin{tabular}{|c|c|c|c|c|c|c|c|c|c|c|c|c|}
\hline \multirow{2}{*}{ Variabel\&Indikator } & \multicolumn{2}{|l|}{1} & \multicolumn{2}{|l|}{2} & \multicolumn{2}{|l|}{3} & \multicolumn{2}{|l|}{4} & \multicolumn{2}{|l|}{5} & \multirow[b]{2}{*}{ Mean } & \multirow[b]{2}{*}{ Kategori } \\
\hline & $\mathbf{F}$ & $\%$ & $\mathbf{F}$ & $\%$ & $\mathbf{F}$ & $\%$ & $\mathbf{F}$ & $\%$ & $\mathbf{F}$ & $\%$ & & \\
\hline Gaya Kepemimpinan (X1) & & & & & & & & & & & 3.22 & Cukup \\
\hline Karismatik (X1.1) & & & & & & & & & & & 3.11 & Cukup \\
\hline $\mathrm{X} 1.1 .1$ & 2 & 3.8 & 7 & 13,53 & 32 & 61.5 & 11 & 21.2 & 0 & 0 & 3.00 & Cukup \\
\hline $\mathrm{X} 1.1 .2$ & 1 & 1.9 & 9 & 17.32 & 20 & 38.5 & 19 & 36.5 & 3 & 5.8 & 3.27 & Cukup \\
\hline $\mathrm{X} 1.1 .3$ & 3 & 5.8 & 6 & 11.52 & 27 & 51.9 & 16 & 30.5 & 0 & 0 & 3.08 & Cukup \\
\hline Stimulasi Intelektual (X1.2) & & & & & & & & & & & 3.18 & Cukup \\
\hline $\mathrm{X} 1.2 .1$ & 3 & 5.8 & 10 & 19.22 & 25 & 48.1 & 10 & 19.2 & 4 & 7.7 & 3.04 & Cukup \\
\hline $\mathrm{X} 1.2 .2$ & 0 & 0 & 8 & 15.42 & 28 & 53.8 & 12 & 23.1 & 4 & 7.7 & 3.23 & Cukup \\
\hline $\mathrm{X} 1.2 .3$ & 0 & 0 & 5 & 9.63 & 32 & 61.5 & 11 & 21.2 & 4 & 7.7 & 3.27 & Cukup \\
\hline Perhatian Secara Intelektual (X1.3) & & & & & & & & & & & 3.38 & Cukup \\
\hline $\mathrm{X} 1.3 .1$ & 0 & 0 & 9 & 17.32 & 21 & 40.4 & 22 & 42.3 & 0 & 0 & 3.25 & Cukup \\
\hline $\mathrm{X} 1.3 .2$ & 1 & 1.9 & 5 & 9.62 & 25 & 48.1 & 21 & 40.4 & 0 & 0 & 3.27 & Cukup \\
\hline $\mathrm{X} 1.3 .3$ & 0 & 0 & 9 & 17.3 & 9 & 17.3 & 34 & 65.4 & 0 & 0 & 3.48 & Cukup \\
\hline $\mathrm{X} 1.3 .4$ & 0 & 0 & 5 & 9.61 & 16 & 30.8 & 30 & 57.7 & 1 & 1.9 & 3.52 & Cukup \\
\hline Disiplin Kerja (X2) & & & & & & & & & & & 3.85 & Baik \\
\hline Disiplin Preventif (X2.1) & & & & & & & & & & & 3.82 & Baik \\
\hline $\mathrm{X} 2.1 .1$ & 0 & 0 & 2 & 3.8 & 5 & 9.6 & 2 & 3.8 & 43 & 82.7 & 4.65 & Sangat \\
\hline $\mathrm{X} 2.1 .2$ & 1 & 1.9 & 6 & 11.51 & 16 & 30.8 & 16 & 30.8 & 13 & 25.0 & 3.65 & Baik \\
\hline
\end{tabular}




\begin{tabular}{|l|c|c|c|c|c|c|c|c|c|c|c|c|}
\hline X2.1.3 & 1 & 1.9 & 23 & 44.2 & 14 & 26.9 & 14 & 26.9 & 0 & 0 & 2.79 & Cukup \\
\hline X2.1.4 & 0 & 0 & 3 & 5.8 & 21 & 40.4 & 19 & 36.5 & 9 & 17.3 & 3.65 & Baik \\
\hline X2.1.5 & 0 & 0 & 0 & 0 & 10 & 19.2 & 11 & 21.2 & 31 & 59.6 & 4.40 & Sangat \\
\hline Disiplin Korektif (X2.2) & & & & & & & & & & & $\mathbf{3 . 8 8}$ & Baik \\
\hline X2.2.1 & 0 & 0 & 15 & 28.8 & 7 & 13.5 & 6 & 11.5 & 24 & 46.2 & 3.75 & Baik \\
\hline X2.2.2 & 0 & 0 & 6 & 11.5 & 13 & 25.0 & 25 & 48.1 & 8 & 15.4 & 3.67 & Baik \\
\hline X2.2.3 & 0 & 0 & 2 & 3.8 & 7 & 13.5 & 23 & 44.2 & 20 & 38.5 & 4.17 & Baik \\
\hline X2.2.4 & 5 & 9.6 & 5 & 9.6 & 5 & 9.6 & 10 & 19.2 & 27 & 51.9 & 3.94 & Baik \\
\hline Kinerja Karyawan (Y) & & & & & & & & & & & $\mathbf{3 . 6 8}$ & Baik \\
\hline Faktor Kemampuan (Y1.1) & & & & & & & & & & & $\mathbf{3 . 7 7}$ & Baik \\
\hline Y1.1.1 & 0 & 0 & 5 & 9.6 & 3 & 5.8 & 14 & 26.9 & 30 & 57.7 & 4.33 & Sangat \\
\hline Y1.1.2 & 2 & 3.8 & 1 & 1.9 & 6 & 11.5 & 25 & 48.1 & 18 & 34.6 & 4.08 & Baik \\
\hline Y1.1.3 & 0 & 0 & 3 & 5.8 & 8 & 15.4 & 31 & 59.6 & 10 & 19.2 & 3.92 & Baik \\
\hline Y1.1.4 & 1 & 1.9 & 21 & 40.4 & 14 & 26.9 & 16 & 30.8 & 0 & 0 & 2.87 & Cukup \\
\hline Y1.1.5 & 1 & 1.9 & 6 & 11.5 & 2 & 3.8 & 43 & 82.7 & 0 & 0 & 3.67 & Baik \\
\hline Kemampuan Motivasi (Y1.2) & & & & & & & & & & & $\mathbf{3 . 5 9}$ & Baik \\
\hline Y1.2.1 & 2 & 3.8 & 3 & 5.8 & 11 & 21.2 & 36 & 69.2 & 0 & 0 & 3.56 & Baik \\
\hline Y1.2.2 & 0 & 0 & 10 & 19.2 & 33 & 63.5 & 9 & 17.3 & 0 & 0 & 2.98 & Cukup \\
\hline Y1.2.3 & 0 & 0 & 4 & 7.7 & 7 & 13.5 & 31 & 59.6 & 10 & 19.2 & 3.90 & Baik \\
\hline Y1.2.4 & 0 & 0 & 1 & 1.9 & 12 & 23.129 & 55.8 & 10 & 19.2 & 3.92 & Baik \\
\hline
\end{tabular}

Sumber: Data diolah

Berdasarkan tabel di atas, indikator-indikator pada tiap dimensi karismatik, stimulasi intelektual dan perhatian intelektual pada variabel gaya kepemimpinan mempunyai nilai mean diatas 3 berarti mempunyai kecenderungan respon yang cukup baik. Indikator yang mempunyai respon negatif tertinggi sebagai berikut, dimensi karismatik pada indikator X1.1.1 mempunyai respon negatif sebesar 3.00, artinya responden dalam hal ini yang merupakan karyawan PT XYZ Divisi EPC merasa bahwa pimpinan belum memberikan motivasi untuk karyawan secara optimal.

Variabel kedua yaitu disiplin kerja, indikator pada dimensi disiplin kerja mempunyai nilai mean sebesar 3.85 yang artinya mempunyai kecenderungan respon yang baik. Dimensi disiplin preventif pada indikator X2.1.1 mempunyai respon positif tertinggi sebesar 4.65 dimana karyawan menaati segala peraturan yang telah ditetapkan. Hal ini dibuktikan bahwa karyawan menaati peraturan sudah dibuat oleh perusahaan dan harus diterapkan oleh masing-masing karyawan.

Variabel ketiga yaitu pada variabel kinerja karyawan mempunyai nilai mean sebesar 3.68 yang artinya mempunyai kecenderungan respon yang baik. Dimensi faktor kemampuan pada indikator Y1.1.4 mempunyai respon negatif tertinggi sebesar 2.87 dimana karyawan belum menjaga sikap dalam lingkungan kerja. Hal ini dibuktikan bahwa masih ada karyawan yang belum menjaga sikap dalam lingkungan kerja sehingga lingkungan kerja belum terasa nyaman bagi karyawan yang lain. Dimensi kemampuan motivasi pada indikator Y2.2.2 mempunyai respon negatif tertinggi sebesar 2.98 dimana semakin tinggi pendidikannya semakin bagus kinerjanya. Hal ini dibuktikan bahwa tingkat pendidikan yang semakin tinggi mempengaruhi jabatan setiap karyawan. 


\section{Uji Validitas}

Berikut ini adalah hasil output factor loading konstruk gaya kepemimpinan, disiplin kerja dan kinerja karyawan pada PLS :

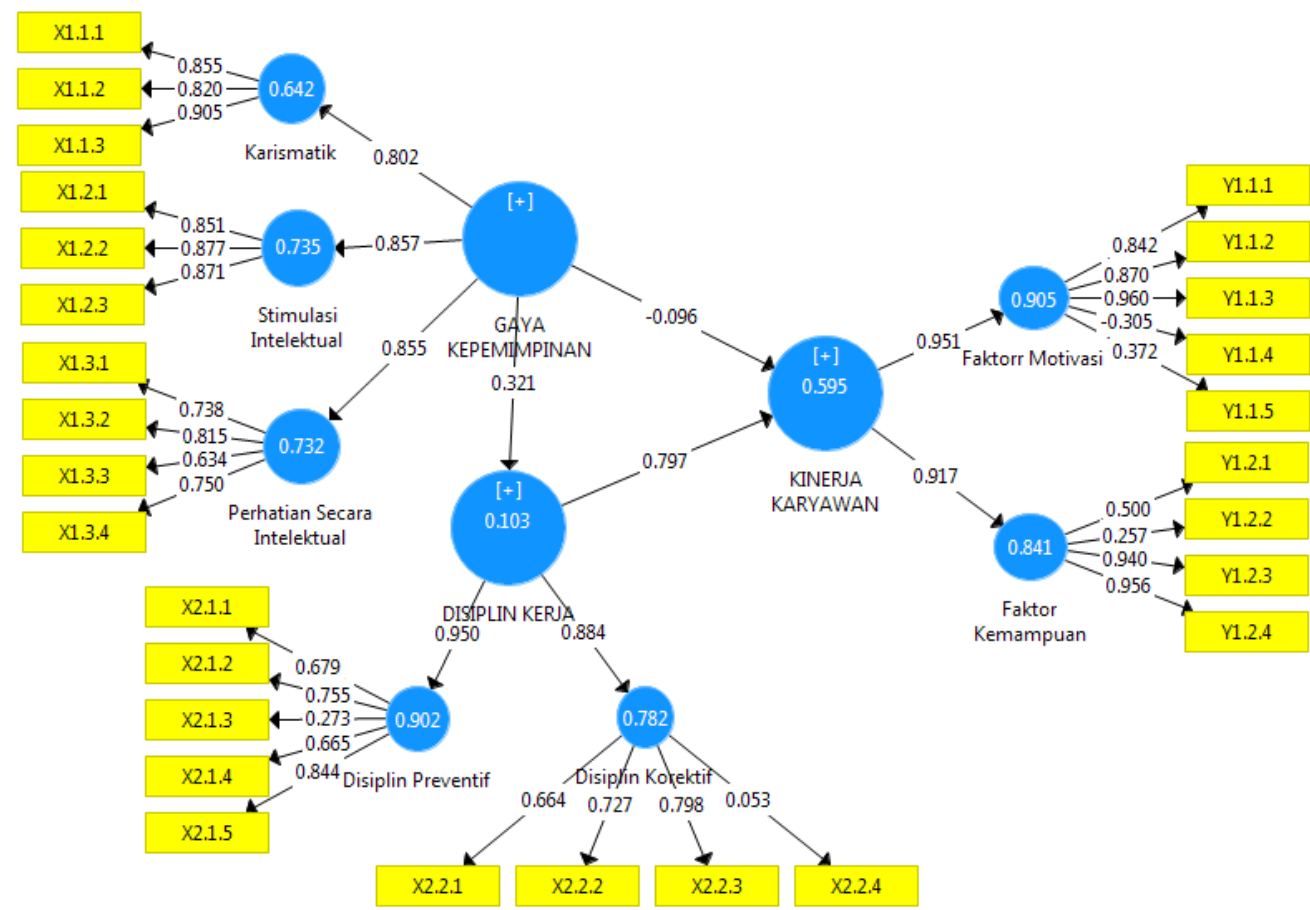

Gambar 3. Loading Factor Variabel Penelitian Sebelum di Drop Sumber : Hasil diolah Smart PLS

Berdasarkan nilai factor loading di atas, masih terdapat factor loading yang nilainya di bawah 0,5. Karena memiliki nilai convergent validity yang rendah, maka indikator-indikator yang memiliki loading factor dibawah 0,5 tersebut harus didrop, berdasarkan output di atas indikator X2.1.3, X2.2.4, Y1.1.4, Y1.1.5, Y1.2.1, dan Y1.2.2 loadingnya masih di bawah 0,5 sehingga indikator tersebut harus di drop.

\section{Uji Reabilitas}

Dalam penelitian, suatu variabel dikatakan cukup reliabilitas bila variabel tersebut mempunyai nilai construct reliability lebih besar dari 0,6. Berikut ini adalah tabel hasil pengujian reliabilitas pada masing-masing dimensi pada variabel laten gaya kepemimpinan, disiplin kerja dan kinerja karyawan.

Tabel 4. Pengujian Reliabilitas

\begin{tabular}{|l|l|l|l|}
\hline Variabel \& Dimensi & AVE & $\begin{array}{l}\text { Composite } \\
\text { Reability }\end{array}$ & $\begin{array}{l}\text { Cronbachs } \\
\text { Alpha }\end{array}$ \\
\hline GAYA KEPEMIMPINAN (X1) & 0.466 & 0.896 & 0.870 \\
\hline Karismatik & 0.741 & 0.895 & 0.824 \\
\hline Stimulasi Intelektual & 0.750 & 0.900 & 0.834 \\
\hline Perhatian Secara Intelektual & 0.543 & 0.825 & 0.718 \\
\hline
\end{tabular}




\begin{tabular}{|l|l|l|l|} 
DISIPLIN KERJA (X2) & 0.316 & 0.812 & 0.731 \\
\hline Disiplin Preventif & 0.554 & 0.831 & 0.727 \\
\hline Disiplin Korektif & 0.540 & 0.788 & 0.594 \\
\hline KINERJA KARYAWAN (Y) & 0.459 & 0.831 & 0.776 \\
\hline Faktor Kemampuan & 0.943 & 0.971 & 0.940 \\
\hline Faktor Motivasi & 0.819 & 0.931 & 0.888 \\
\hline
\end{tabular}

Sumber : Hasil diolah Smart PLS

Berdasarkan hasil output reliabilitas di atas, dapat disimpulkan bahwa untuk variabel gaya kepemimpinan, disiplin kerja dan kinerja karyawan memiliki composite reliability diatas 0.7 sehingga dapat disimpulkan bahwa indikator-indikator yang digunakan pada masing-masing dimensi mempunyai reabilitas yang cukup baik atau mampu untuk mengukur kontruknya.

Berdasarkan hasil analisis validitas dan reabilitas diatas, pengaruh second order kontruk gaya kepemimpinan, disiplin kerja dan kinerja karyawan berpengaruh terhadap dimensi kinerja karyawan kontruk faktor kemampuan dan faktor motivasi dengan nilai cronbachs alpha tertinggi. Sehingga dapat disimpulkan bahwa kontruk gaya kepemimpinan dibentuk oleh tiga dimensi yaitu karismatik, stimulasi interlektual dan perhatian secara intelektual. Kontruk disiplin kerja dibentuk oleh dua dimensi yaitu dimensi disiplin preventif dan disiplin korektif. Kontruk kinerja dibentuk oleh dua dimensi yaitu faktor kemampuan dan faktor motivasi.

\section{Evaluasi Goodness Of Fit Model Stuktural (Inner Model)}

Evaluasi goodness of fit model struktural diukur dengan menggunakan nilai predivtiverelevance $\left(\mathrm{Q}^{2}\right)$. Nilai predictive-relevance $\left(\mathrm{Q}^{2}\right)$ dihitung dengan menggunakan rumus sebagai berikut :

$$
\begin{aligned}
\mathrm{Q}^{2} & =1-\left(1-\mathrm{R}^{2}{ }_{1)}\left(1-\mathrm{R}^{2}{ }_{2}\right)\right. \\
\mathrm{Q}^{2} & =1-(1-0.097)(1-0.592) \\
& =1-(0.903)(0.408) \\
& =1-(0.368) \\
& =0.632
\end{aligned}
$$

$\mathrm{R}^{2}$ adalah koefisien determinasi yang merupakan bagian dari variasi total dalam variabel dependen yang dijelaskan oleh variasi dalam variabel independen. Tabel 5 berikut ini menjelaskan hasil analisis koefisien determinasi dari variabel-variabel penelitian :

Tabel 5. $R$ Square

\begin{tabular}{|l|l|}
\hline Variabel & R Square \\
\hline Disiplin Kerja $(\mathrm{X} 2)$ & 0.097 \\
\hline Kinerja Karyawan $(\mathrm{Y})$ & 0.592 \\
\hline Predictive-Relevance $\left(\mathrm{Q}^{2}\right)$ & 0.632 \\
\hline
\end{tabular}

Sumber : Hasil diolah Smart PLS

Berdasarkan koefisien determinasi pada tabel diatas, diperoleh nilai $\mathrm{R}^{2}$ untuk variabel disiplin kerja sebesar 0.097, yang artinya nilai tersebut mengindikasikan bahwa variabel disiplin kerja dapat dijelaskan oleh variabel gaya kepemimpinan sebesar $0,97 \%$ sedangkan sisanya yaitu sebesar 99,03\% dipengaruhi oleh variabel lain yang tidak terdapat dalam model penelitian dan variabel kinerja karyawan sebesar 0.592, yang artinya nilai tersebut mengindikasikan bahwa variasi kinerja karyawan dapat dijelaskan oleh variasi gaya kepemimpinan dan disiplin kerja 
sebesar 59,2\% sedangkan sisanya yaitu sebesar 40,8\% dipengaruhi variabel lain yang tidak terdapat dalam model penelitian. Sedangkan nilai predictive-relevance untuk model struktural dalam penelitian ini adalah sebesar 0.632 atau 63,2\% artinya model mampu menjelaskan fenomena kinerja karyawan dikaitkan dengan beberapa variabel, yaitu gaya kepemimpinan dan disiplin kerja. Oleh karena itu model dapat dikatakan cukup baik, atau model memiliki nilai prediktif yang sangat baik. Pada akhirnya model dapat digunakan untuk pengujian hipotesis.

\section{Pengujian Hipotesis}

Untuk menguji hipotesis dalam penelitian ini, digunakan nilai t-statistik pada masingmasing jalur pengaruh langsung secara parsial. Berdasarkan pengujian hipotesis, semua dimensi pada masing-masing variabel mempunyai nilai $\mathrm{T}_{\text {statistics }}$ lebih besar dari 1,660 sehingga dimensi-dimensi tersebut mampu mengukur setiap konstruknya. Sedangkan untuk menguji hubungan antar variabel (uji hipotesis), maka digunakan nilai tstatistik dari output Smart PLS yang dibandingkan dengan nilai $\mathrm{T}_{\text {tabel. }}$. Berikut ini adalah tabel yang memberikan hasil hubungan antar konstruk (variabel).

Tabel 6. Path Coefficients (Mean, STDEV, P-Values)

\begin{tabular}{|l|l|l|l|l|}
\hline Hubungan Antar Variabel & $\begin{array}{l}\text { Koefisien } \\
\text { Parameter }\end{array}$ & $\begin{array}{r}\text { T } \\
\text { Statistic }\end{array}$ & P Value & Keterangan \\
\hline Kinerja Karyawan ->Faktor Motivasi & 0.943 & 40.304 & 0.000 & Signifikan** \\
\hline $\begin{array}{l}\text { Kinerja Karyawan -> Faktor } \\
\text { Kemampuan }\end{array}$ & 0.920 & 38.901 & 0.000 & Signifikan** \\
\hline $\begin{array}{l}\text { Gaya Kepemimpinan -> Stimulasi } \\
\text { Intelektual }\end{array}$ & 0.857 & 22.780 & 0.000 & Signifikan** \\
\hline $\begin{array}{l}\text { Gaya Kepemimpinan -> Perhatian } \\
\text { Secara Intelektual }\end{array}$ & 0.855 & 24.070 & 0.000 & Signifikan** \\
\hline $\begin{array}{l}\text { Gaya Kepemimpinan -> Karismatik } \\
\text { Gaya Kepemimpinan -> Disiplin } \\
\text { Kerja }\end{array}$ & 0.802 & 10.587 & 0.000 & Signifikan** \\
\hline $\begin{array}{l}\text { Gaya Kepemimpinan -> Kinerja } \\
\text { Karyawan }\end{array}$ & -0.091 & 0.792 & 0.214 & $\begin{array}{l}\text { Tidak } \\
\text { Signifikan }\end{array}$ \\
\hline Disiplin Kerja ->Kinerja Karyawan & 0.793 & 9.972 & 0.000 & Signifikan** \\
\hline Disiplin Kerja ->Disiplin Preventif & 0.946 & 72.037 & 0.000 & Signifikan** \\
\hline Disiplin Kerja ->Disiplin Korektif & 0.879 & 29.545 & 0.000 & Signifikan** \\
\hline $\begin{array}{l}\text { Gaya Kepemimpinan -> Kinerja } \\
\text { Karyawan Melalui Disiplin Kerja }\end{array}$ & 0.247 & 1.948 & 0.026 & Signifikan** \\
\hline Ket: & & 0.013 & Signifikan** \\
\hline
\end{tabular}

Ket: **Signifikan pada level 5\%, * Signifikan pada level 10\%

Sumber : Hasil diolah Smart PLS 
Berdasarkan diagram jalur penelitian di atas, kemudian diterjemahkan ke dalam bentuk persamaan sebagai berikut :

$$
\begin{aligned}
& \mathrm{DK}=0,312 \mathrm{GK}+\mathrm{e} 1 \ldots \ldots \ldots \ldots \ldots \ldots \ldots . . .(1) \\
& \mathrm{KK}=-0,091 \mathrm{GK}+0,793 \mathrm{DK}+0.247 \mathrm{GKDK}+\mathrm{e} 2
\end{aligned}
$$

Pada model penelitian pertama, pengaruh Gaya Kepemimpinan terhadap Disiplin Kerja mempunyai nilai koefisien regresi sebesar 0,312 artinya ketika Gaya Kepemimpinan meningkat (bertambah 1) maka Disiplin Kerja akan naik sebesar 0,312. Begitu juga sebaliknya, jika Gaya Kepemimpinan menurun (berkurang) maka Disiplin Kerja pun akan menurun.

Pada model penelitian kedua, Gaya Kepemimpinan tidak ada pengaruhnya jika dibandingkan dengan Disiplin Kerja, dengan koefisien regresi sebesar -0,091 sedangkan Disiplin Kerja terhadap Kinerja Karyawan berpengaruh sangat besar 0.793. Artinya ketika Disiplin Kerja meningkat (bertambah) maka Kinerja Karyawan juga meningkat.

\section{Pengaruh Gaya Kepemimpinan Terhadap Disiplin Kerja}

Berdasarkan uji hipotesis Koefisien parameter jalur yang diperoleh dari pengaruh variabel gaya kepemimpinan terhadap disiplin kerja adalah sebesar 0.312 dengan nilai $\mathrm{T}_{\text {statistik }} 2.233$ > 1.660 pada taraf signifikansi $\alpha=0.05(5 \%)$ yang menyatakan bahwa terdapat pengaruh positif antara gaya kepemimpinan terhadap disiplin kerja. Nilai 0.312 pada koefisien parameter artinya adalah semakin baik gaya kepemimpinan maka disiplin kerja akan semakin baik. Hasil penelitian ini mendukung hipotesis pertama, dimana terdapat pengaruh positif dan signifikan antara gaya kepemimpinan terhadap disiplin kerja. Hasil ini menunjukkan bahwa dengan semakin baik gaya kepemimpinan maka kedisiplinan karyawan dalam bekerja akan meningkat. Hal ini sejalan dengan penelitian yang di dokumentasikan oleh Rivai dan Jauvani (2009), Liyas (2017), dan Muthi dan Djuwita (2019) yang menunjukkan bahwa gaya kepemimpinan berpengaruh positif terhadap variabel disiplin kerja.

\section{Pengaruh Gaya Kepemimpinan Terhadap Kinerja Karyawan}

Hasil pengujian hipotesis penelitian kedua ditolak bahwa tidak terdapat pengaruh signifikan gaya kepemimpinan terhadap kinerja karyawan. Hasil penelitian ini tidak mendukung hipotesis yang kedua, dimana gaya kepemimpinan bukan factor yan menentukan kinerja karyawan. Hasil penelitian ini tidak sesuai dengan peneliti sebelumnya yaitu Susanty dan Baskoro (2012), Wiratama dan Sintaasih (2013), Putra (2014), Iqbal et al. (2015), Chandra (2016), Fathia et al. (2018), Jayanti \& Wati (2019), namun mendukung penelitian sebelumnya yang didokumentasikan oleh Ariyani dan Ariyanto (2011), dimana gaya kepemimpinan tidak berpengaruh terhadap kinerja karyawan. Gaya kepemimpinan bukanlah factor penentu kinerja karyawan secara langsung di PT. XYZ Divisi EPC.

\section{Pengaruh Disiplin Kerja Terhadap Kinerja Karyawan}

Berdasarkan hasil pengujian hipotesis penelitian ketiga menunjukkan bahwa terdapat pengaruh signifikan disiplin kerja terhadap kinerja karyawan. Hasil ini menunjukkan bahwa semakin baik disiplin kerja karyawan, maka kinerja karyawan juga akan baik dalam bekerja. Hal ini sejalan dengan penelitian yang di dokumentasikan oleh Susanty dan Baskoro (2012), Wiratama dan Sintaasih (2013), Putra (2014), Suyono (2014), Hersona \& Sidharta (2016), Fathia et al. (2018), dalam penelitiannya menunjukkan bahwa disiplin kerja berpengaruh positif terhadap variabel kinerja karyawan.

\section{Pengaruh Gaya Kepemimpinan Terhadap Kinerja Karyawan Melalui Disiplin Kerja}

Berdasarkan hasil pengujian hipotesis penelitian keempat, terdapat pengaruh positif dan signifikan gaya kepemimpinan terhadap kinerja karyawan melalui disiplin kerja. Hasil ini 
mendukung hipotesis penelitian keempat, dimana terdapat pengaruh positif dan signifikan antara gaya kepemimpinan terhadap kinerja karyawan melalui disiplin kerja. Hasil ini menunjukkan bahwa semakin baik pengaruh gaya kepemimpinan, maka disiplin kerja karyawan juga akan meningkat dan berdampak terhadap meningkatnya kinerja karyawan. Hal ini sejalan dengan penelitian yang di dokumentasikan oleh Susanty dan Baskoro (2012) dalam penelitiannya menunjukkan bahwa terdapat pengaruh positif antara gaya kepemimpinan terhadap terhadap disiplin kerja dan kinerja karyawan. Disiplin kerja merupakan variable intervening karena mampu memediasi pengaruh gaya kepemimpinan terhadap kinerja karyawan.

\section{PENUTUP}

Berdasarkan hasil penelitian baik melalui analisis deskriptif maupun analisis verifikatif, PT. XYZ Divisi EPC dalam gaya kepemimpinan belum sesuai dengan apa yang diharapkan karyawan. Ada beberapa hal ketidaksesuian yang masih dilakukan pemimpin terkait dengan masalah pemimpin yaitu belum optimal dalam memotivasi karyawan, dan komunikasi yang kurang baik antara pemimpin dengan karyawan. Secara empiris, gaya kepemimpinan berpengaruh positif dan signifikan terhadap disiplin kerja, sehingga ketika gaya kepemimpinan meningkat maka disiplin kerja pun akan meningkat. Disiplin kerja berpengaruh positif dan signifikan terhadap kinerja karyawan. Gaya kepemimpinan tidak berpengaruh signifikan terhadap kinerja karyawan secara langsung namun berpengaruh signifikan secara tidak langsung melalui disiplin kerja, sehingga ketika gaya kepemimpinan meningkat maka disiplin kerja karyawan pun akan meningkat dan akan meningkatkan kinerja karyawan.

Keterbatasan penelitian ini tidak menggunakan teknik wawancara sehingga pengumpulan data hanya berdasarkan kuesioner yang telah disebarkan kepada responden yaitu karyawan PT XYZ Divisi EPC. Berdasarkan hasil penelitian, disarankan masih perlu adanya pelatihan tentang kepemimpinan yang diikuti oleh pemimpin divisi agar para pemimpin divisi memiliki pengetahuan yang cukup tentang gaya kepemimpinan seperti apa yang dapat meningkatkan disiplin dan kinerja karyawan di perusaahannya. Perlu adanya peningkatan kedisiplinan karyawan dan peningkatan hubungan kerjasama serta komunikasi yang baik antara Pimpinan dengan karyawan maupun sesama karyawan. Untuk meningkatkan kedisiplinan kerja perlu adanya Pimpinan yang tegas agar karyawan menaati peraturan yang sudah ditetapkan oleh perusahaan. Keterbatasan penelitian ini tidak menggunakan teknik wawancara sehingga pengumpulan data hanya berdasarkan hasil data dari kuisioner yang telah terkumpul berdasarkan kuisioner yang telah disebarkan kepada responden yaitu karyawan PT XYZ Divisi EPC.

\section{REFERENSI}

Ardana dkk, I Komang, (2012). Manajemen Sumber Daya Manusia. Graha Ilmu: Yogyakarta.

Chandra, T. (2016). The Influence of Leadership Styles, Work Environment and Job Satisfaction of Employee Performance--Studies in the School of SMPN 10 Surabaya. International Education Studies, 9(1), 131-140.

Davis, Keith dan John W. Newstrom, (1985). Perilaku Dalam Organisasi. Erlangga: Jakarta.

Handoko, T. Hani, (2008). Manajemen Personalia Dan Sumber Daya Manusia Edisi Kedua. BPFE Yogyakarta: Yogyakarta

Hersona, S., \& Sidharta, I. (2017). Influence Of Leadership Function, Motivation And Work Discipline On Employees'performance. Jurnal Aplikasi Manajemen, 15(3), 528-537.

Iqbal, N., Anwar, S., \& Haider, N. (2015). Effect of leadership style on employee performance. Arabian Journal of Business and Management Review, 5(5), 1-6. 
Jayanti, K.T., \& Wati, L.N. 2019. Pengaruh Gaya Kepemimpinan Terhadap Kinerja Karyawan dan Dampaknya Terhadap Loyalitas Karyawan. Jurnal Ekobis: Ekonomi, Bisnis dan Manajemen. Vol. 9 No. 2.

Kurniawan, I., \& Santoso, A. (2012). Analisis pengaruh kepemimpinan, disiplin kerja, dan motivasi kerja terhadap kinerja karyawan PT Prima Zirang Utama Semarang. Skripsi. Semarang: Fakultas Ekonomi, Universitas Semarang.

Liyas, J. N. (2017). Pengaruh Kepemimpinan Terhadap Disiplin Kerja Karyawan Pada PT. BANK Syariah Mandiri. JEBI (Jurnal Ekonomi dan Bisnis Islam), 2(2), 121-129.

Mangkunegara, A.P. (2010). Manajemen Sumber Daya Manusia Perusahaan. PT. Rosda: Bandung.

Muthi, S. S., \& Djuwita, A. (2019). Pengaruh Gaya Kepemimpinan Terhadap Disiplin Kerja Dilingkungan Telkom Regional Iii Jawa Barat. eProceedings of Management, 6(2).

Putra, G. P. U. (2014). Pengaruh Disiplin Kerja, Gaya Kepemimpinan, dan Motivasi Kerja Terhadap Kinerja Karyawan Pada Hotel Matahari Terbit Bali, Tanjung Benoa-Nusa Dua. E-Jurnal Manajemen, 2(7).

Rivai, V., \& Jauvani, E. (2009). Dari Teori ke Praktik Manajemen Sumber Daya Manusia untuk Perusahaan.

Susanty, A., \& Baskoro, S. W. (2012). Pengaruh motivasi kerja dan gaya kepemimpinan terhadap disiplin kerja serta dampaknya pada kinerja karyawan (studi kasus pada pt. Pln (persero) apd semarang).J@Ti Undip: Jurnal Teknik Industri, 7(2), 77-84.

Suyono, W. G. P. (2014). Pengaruh Motivasi, Kemampuan Dan Disiplin Terhadap Kinerja Karyawan (Studi pada Radio Republik Indonesia Semarang). Jurnal, Fakultas Ekonomi dan Bisnis Universitas Dian Nuswantoro.

Tintami, L., Pradhanawati, A., \& Nugraha, H. S. (2013). Pengaruh Budaya Organisasi dan Gaya Kepemimpinan Transformasional terhadap Kinerja Karyawan Melalui Disiplin Kerja pada Karyawan harian SKT Megawon II PT. Djarum Kudus. Jurnal Ilmu Administrasi Bisnis, l(1), 189-196.

Wati, L.N. (2017). Metodologi Penelitian Bisnis Terapan, Aplikasi SPSS, EVIEWS, Smart PLS, dan AMOS. Percetakan Mujahid: Bandung

Wiratama, I. N. J. A., \& Sintaasih, D. K. (2013). Pengaruh Kepemimpinan, Diklat, dan Disiplin Kerja Terhadap Kinerja Karyawan PDAM Tirta Mangutama Kabupaten Badung. Matrik: Jurnal Manajemen, Strategi Bisnis dan Kewirausahaan. 